\title{
Mixotrophic ciliates in North-Patagonian Andean lakes: stoichiometric balances in nutrient limited environments
}

\author{
Beatriz Modenutti* and Esteban Balseiro
}

Laboratorio de Limnología, INIBIOMA, CONICET-Universidad Nacional del Comahue, Quintral 1250, 8400

Bariloche, Argentina.

* Corresponding author: bmodenutti@comahue-conicet.gob.ar

Received: 23/10/18 Accepted: 17/04/19

\begin{abstract}
Mixotrophic ciliates in North-Patagonian Andean lakes: stoichiometric balances in nutrient limited environments

Transparent ultraoligotrophic lakes in the North-Patagonian Andes have a particular microbial food web, with the presence of large mixotrophic ciliates. These organisms exhibit different features that allow them to colonize either the epilimnion (Stentor araucanus) or the metalimnion (Ophrydium naumanni). S. araucanus is a dark pigmented (stentorin) species resistant to ultraviolet radiation and needs high light supply to maintain endosymbiotic algal photosynthesis. In contrast, O. naumanni dominates the phothosynthetic biomass in the deep chlorophyll maxima (metalimnion) of these lakes, being photosynthetically efficient at low light intensities but susceptible to photoinhibition at epilimnetic light irradiances. Analysis of food vacuoles revealed a weak niche overlap, however light climate, shaped by temporal or spatial variations in thermocline depth, resulted in a key factor modulating the relative success of these mixotrophic ciliate species. Overall, these species are stoichiometrically, carbon to nutrients, more balanced than the bulk seston, but the mechanisms by which each species regulates the elemental balance differ. O. naumanni increases bacterivory with light, thus increasing phosphorus uptake, while $S$. araucanus regulates carbon fixation. The low carbon:nutrient ratio of these organisms would represent a very good food source for zooplankton. Finally, we pointed out that different effects of local and global changes will affect negatively the particular ciliate assemblage of North-Patagonian Andean lakes.
\end{abstract}

Key words: mixotrophy, stoichiometric constrains, transparency

\section{RESUMEN}

Ciliados mixotróficos en lagos andinos norpatagónicos: balances estequiométricos en ambientes limitados por nutrientes

Los lagos andinos nord-patagónicos son ultraoligotróficos, muy transparentes y poseen una red trófica microbiana particular, con la presencia de grandes ciliados mixotróficos. Estos organismos exhiben diferentes características que les permiten colonizar el epilimnion (Stentor araucanus) o el metalimnion (Ophrydium naumanni). S. araucanus es una especie pigmentada oscura (stentorina) resistente a la radiación ultravioleta y que necesita un alto suministro de luz para mantener la fotosíntesis de sus algas endosimbióticas. En contraste, O. naumanni domina la biomasa fotosintética en los niveles de clorofila máxima profunda (metalimnion) de estos lagos, siendo fotosintéticamente eficiente a bajas intensidades de luz, pero susceptible a la fotoinhibición en el epilimnion. El análisis de las vacuolas alimentarias reveló una baja superposición de nichos, sin embargo, el clima óptico, modulado por variaciones temporales o espaciales en la profundidad de la termoclina, resultó un factor clave para la alternancia de estas dos especies. En general, estas especies son estequiométricas más balanceadas (carbono:nutrientes) que el seston, pero los mecanismos por los cuales cada especie regula el equilibrio elemental difieren. O. naumanni aumenta la bacterivoría con la luz, lo que aumenta la incorporación de fósforo, mientras que S. araucanus regula la fijación de carbono. La baja proporción de carbono: nutrientes de estos organismos representa una muy buena fuente de alimento para el zooplancton. Finalmente, señalamos que los diferentes efectos de cambios locales y globales afectarán negativamente esta particular biota de ciliados mixótrofos de los lagos andinos del norte de la Patagonia.

Palabras clave: mixotrofía, restricciones estequiométricas, transparencia 


\section{INTRODUCTION}

Mixotrophy is a nutrition mode that combines both phototrophy and phagotrophy to support growth (Jones, 1997; Stoecker, 1998). The combination of photosynthetic and organic carbon ingestion is very common among protists; thus, this strategy is widely distributed in the eukaryotic tree of life (Stoecker et al., 2009). Photosynthetic capability includes the maintenance of phototrophic structures (organelles or whole cells) inside their cytoplasm (Putt, 1990; Perriss et al., 1994) and in particular, ciliates acquired phototrophy by a transient or permanent association between host and symbiont or preyed organelles (Stoecker et al., 2009). Positive photosynthetic rates were observed both, when ciliates sequester chloroplasts from ingested prey or when photosynthetic cells act as endosymbionts (Reisser et al., 1985; Stoecker \& Silver, 1987; Perriss et al., 1994). Genetic analyses of the endosymbionts of freshwater ciliates have revealed that these algae belong mainly to the chlorophyte lineage (mostly species of the genus Chlorella) (Summerer et al., 2008). Independently of the strategy of photosynthesis acquisition, mixotrophic ciliates may represent an important fraction of autotrophic plankton communities (Laybourn-Parry et al., 1997; Modenutti et al., 2000; Macek et al., 2001; Woelfl \& Geller, 2002).

In Andean-Patagonian transparent and oligotrophic lakes, the presence of an important assemblage of mixotrophic ciliates has been reported (Foissner \& Woelfl, 1994; Modenutti, 1997; Modenutti et al., 2000; Woelfl \& Geller, 2002). In particular, a permanent mixotrophic association has been recorded in ciliates such as the peritrich Ophrydium naumanni and the heterotrich Stentor araucanus (Modenutti, 1997) (Fig.1). These organisms contain photosynthetic endosymbionts (Chlorella sp.) that are capable of replication within the host cell and, when ciliate reproduction takes place, they are distributed into the daughter cells so that successive protist generations are already paired with endosymbionts (Modenutti, 2014). Since mixotrophy requires investment in both photosynthetic and heterotrophic cellular apparatus, the benefits must outweigh these costs (Tittel et al., 2003). Thus, the presence of these mixotrophic ciliates suggests that this is a successful strategy under conditions of abundant light and nutrient limita-
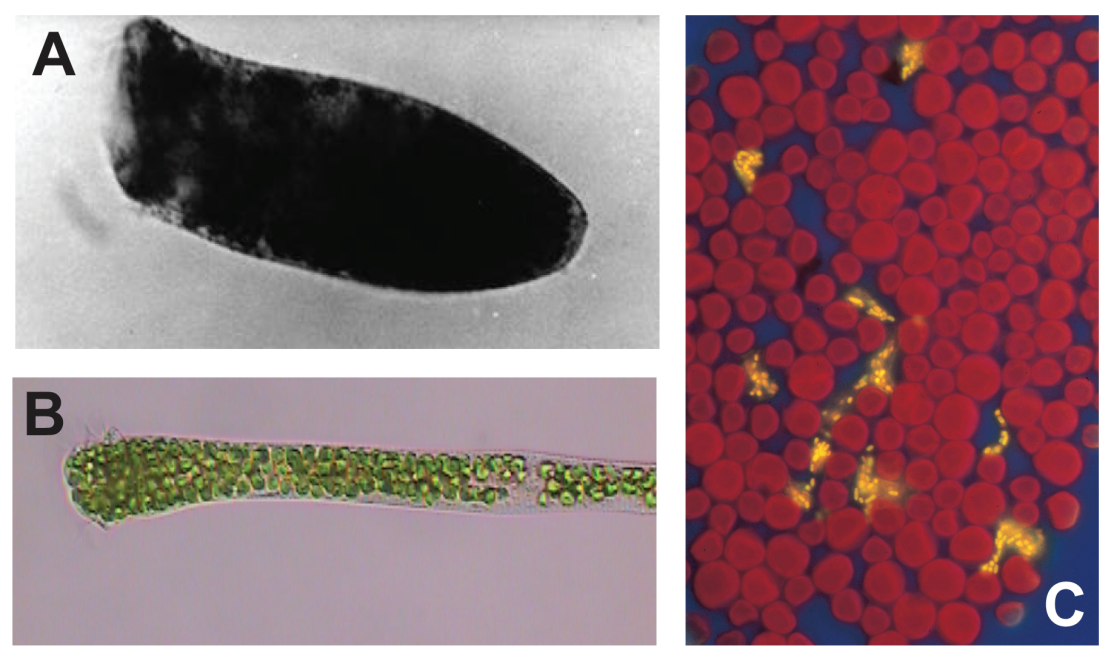

Figure 1. Microphotograph of the mixotrophic ciliates Stentor araucanus (A) and Ophyrdium naumanni (B) under direct microscope and $O$. naumanni $(\mathrm{C})$ under epifluorescent microscope (blue light) showing endosymbiots (Chlorella sp. in red) and prey (picocyanobacteria in yellow). Microfotografía de los ciliados mixotróficos Stentor araucanus (A) y Ophyrdium naumanni (B) ajo microscopio directo y O. naumanni (C) bajo microscopio de epifluorescencia (luz azul) mostrando células endosimbiontes (Chlorella sp. en rojo) y presas (picocianobacterias en amarillo). 
tion as are the features of North-Patagonian Andean lakes of Argentina (Modenutti et al., 2013a). In lake ecosystems, high sestonic Carbon: Phosphorus (C:P) ratios are associated with high light: phosphorus ratios (Sterner et al., 1997). Under high light intensities and low levels of inorganic $\mathrm{P}$, phytoplankton nutrient limitation becomes more severe, resulting in a biomass with a disproportionate accumulation of $\mathrm{C}$ relative to $\mathrm{P}$ (Elser \& Hassett, 1994; Hessen et al., 2002). In this sense, "ecological stoichiometry" has been applied to describe the role of multiple chemical elements in controlling trophic processes (Sterner \& Elser, 2002; Andersen et al., 2004). Thus, herbivore consumers living in transparent lakes would be constrained by poor stoichiometric food quality. However, since mixotrophic ciliates combine phagotrophy and phototrophy their $\mathrm{C}$ :nutrient ratio can be balanced through these two nutritional modes (Flynn \& Mitra, 2009; Mitra et al., 2016). Here, we will analyze two alternative strategies to colonize the water column by two mixotrophic ciliate species $(O$. naumanni and $S$. araucanus) with the final outcome of a balanced stoichiometry. Finally, we will discuss the possible anthropogenic and global effect on these lakes that may affect these two mixotrophic species.

\section{The lakes and the mixotrophic ciliates}

Large and deep lakes in North-Patagonian Andes of Argentina are located in South America around $41{ }^{\circ} \mathrm{S}$ (Fig. 2). They conform an extended lake district from glacial origin shared with Chile and named Araucanian lakes (Thomasson, 1963). Lakes of Argentina are very deep (up to $464 \mathrm{~m}$ in Lake Nahuel Huapi) and are located at $750 \mathrm{~m}$ a.s.1. The lakes are cold-temperate monomictic with a stratification during spring-summer (Baigún \& Marinone, 1995).

These lakes are very transparent environments with extended euphotic zones (up to $50 \mathrm{~m}$ ) that include the epilimnion, the metalimnion and part of the hypolimnion (Fig. 3). Nutrient concentration is low, less than $5 \mu \mathrm{g} / \mathrm{L}$ and $100 \mu \mathrm{g} / \mathrm{L}$ of TP and $\mathrm{TN}$, respectively, and these concentrations are evenly distributed along the water column (Corno et al., 2009). The same pattern was observed for

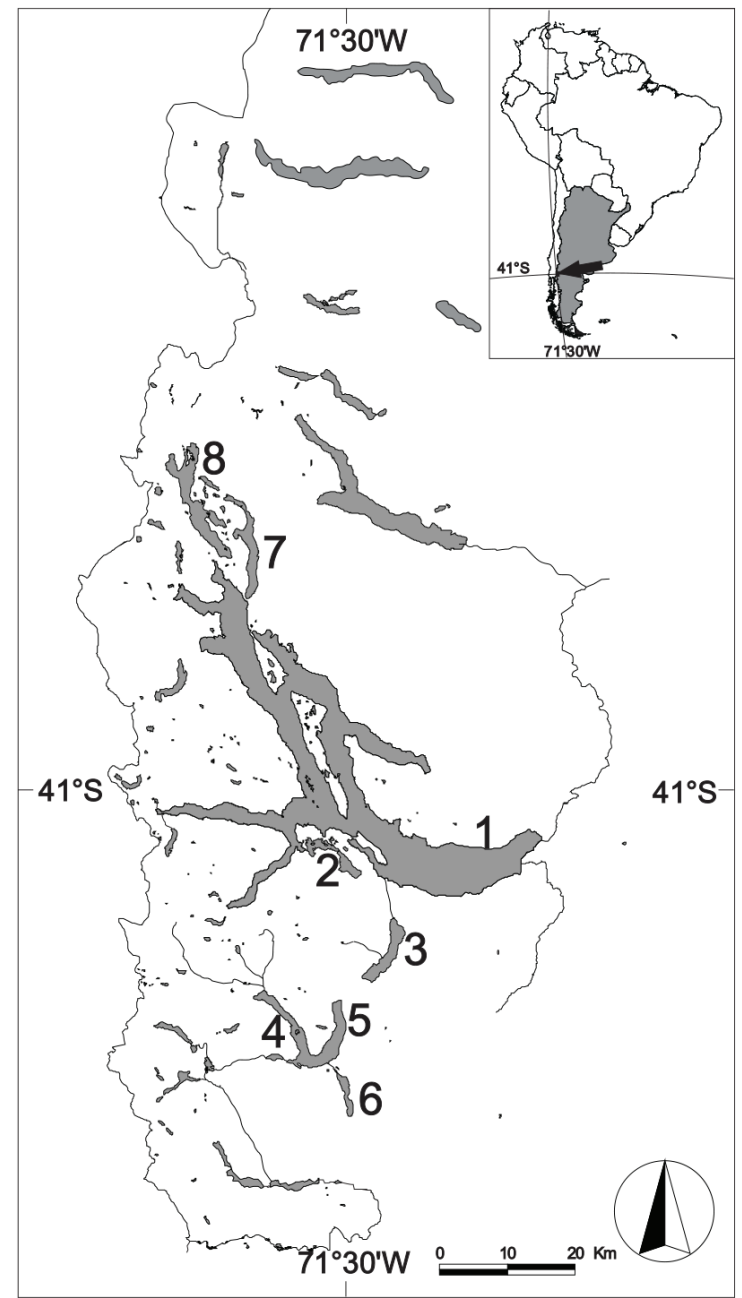

Figure 2. Map of the North Patagonian Andean lake area of Argentina. Numbers indicate most distinctive lakes studied: 1 Nahuel Huapi, 2 Moreno, 3 Gutiérrez, 4 Mascardi Tronador arm, 5 Mascardi Catedral arm, 6 Guillelmo, 7 Correntoso and 8 Espejo. Mapa de los lagos Andinos Norpatagónicos de Argentina. Los números indican los principales lagos estudiados. 1 Nahuel Huapi, 2 Moreno, 3 Gutiérrez, 4 Mascardi Tronador arm, 5 Mascardi Catedral arm, 6 Guillelmo, 7 Correntoso and 8 Espejo.

the dissolved organic carbon (DOC) (less than 0.5 $\mathrm{mg} / \mathrm{L}$ ) (Morris et al., 1995; Modenutti et al., 2013a). This condition causes that the potentially hazardous ultraviolet radiation (UVR) affects an extended portion of the euphotic zone because of the high penetration of the short wavelengths (UVR-A and UVR-B) (Fig. 3). In addition, and also due to the low DOC concentration (low 


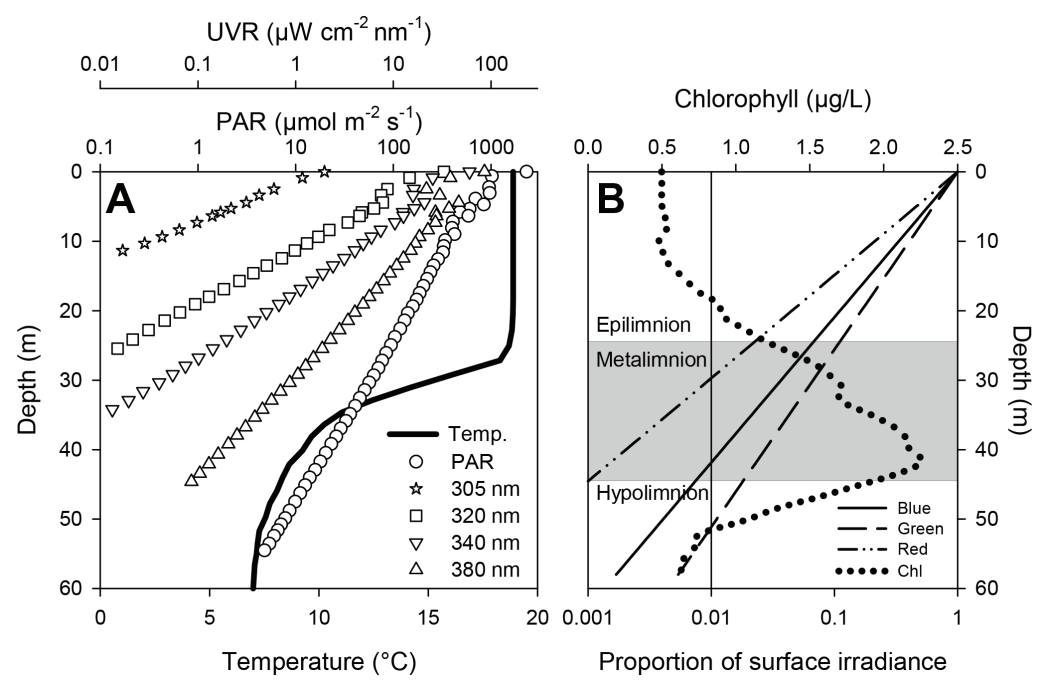

Figure 3. Light, temperature and Chlorophyll $a$ vertical profile in deep north Patagonian lakes of Argentina. (A) Light (PAR, and four bands of UVR) and temperature vertical profiles in a typical north Patagonian deep lake of Argentina. (B) Vertical profiles of specific colours, showing the predominance of blue-green light in the metalimnion, and Chlorophyll a vertical profiles showing the presence of a deep chlorophyll maxima (DCM) at the metalimnion. Perfiles verticales de luz, temperatura y clorofila a de lagos profundos norpatagónicos de Argentina. (A) Perfiles verticales de temperatura y de luz fotosintéticamente activa (PAR) y cuatro bandas de radiación ultravioleta (UVR). (B) Perfiles verticales de colores especificos mostrando la predominancia de azul y verde en el metalimnion, y un perfil vertical de clorofila a mostrando la existencia de un máximo profundo de clorofila (DCM) en el metalimnion.

chromophoric dissolved organic matter), optical quality of the lakes is characterized by a relative rapid attenuation of red light while blue and green light penetrate deeper (Pérez et al., 2002) (Fig. 3). Thus, these environments have been defined as high light/low nutrient environments (Balseiro et al., 2004). Among the peculiarities of their biota, the peritrich $O$. naumanni and the heterotrich $S$. araucanus, both with stable association with endosymbiotic algae, have been recorded since the early studies of Thomasson (1963). Further studies have indicated that these ciliate species are restricted to the more transparent and deeper lakes of the area (Modenutti, 1997).

Under high light scenarios including UVR, a strong photoinhibition effect can occur (Lesser, 1996; Falkowski \& Raven, 2007). As expected, in the upper $10 \mathrm{~m}$ layer of the water column (Fig. 3) there is a strong photoinhibition for autotrophs (Villafañe et al., 2004) that causes low photosynthetic efficiency (Callieri et al., 2007). In addition, due to the UVR effect, plankton avoid upper layers during daytime (Alonso et al., 2004; Balseiro et al., 2007; Modenutti et al., 2018) with the exception of the pigmented ciliate $S$. araucanus (Modenutti et al., 1998; Modenutti et al., 2005). However, as a counterpart, light is not limiting for autotrophs at least up to $\sim 30-40 \mathrm{~m}$ of the water column, and implies the development of deep chlorophyll maxima (DCM) located mainly in the metalimnion (Modenutti et al., 2013a). Accordingly, the highest photosynthetic efficiency was observed near the $1 \%$ of surface PAR (photosynthetically active radiation) (Callieri et al., 2007). These DCM are constituted by endosymbiotic algae of O. naumanni (Queimaliños et al., 1999), picocyanobacteria (Callieri et al., 2007), dinoflagellates and nanoflagellates (Modenutti et al., 2013a). Interestingly, predator and prey $(O$. naumanni and picocyanobacteria) coexist at this level (Modenutti \& Balseiro, 2002).

\section{Light protection or surface avoidance}

To cope with scenarios of extremely high epilimnetic irradiances in these Andean lakes, mixotrophic ciliates exhibit two different strategies: a strong photoprotection (Modenutti et al., 
2005) or the avoidance of the upper levels of the water column (Modenutti et al., 2004). The highly illuminated epilimnetic layers include both PAR and UVR wavelengths, and the net effect on the phytoplankton community at these upper levels is a strong photoinhibition with DNA damage and very low phytoplanktonic biomass (Villafañe et al., 2004). Nevertheless, these upper levels of the water column are colonized by the mixotrophic ciliate $S$. araucanus (Woelfl \& Geller, 2002) that presents an extremely high resistance to UVR (Modenutti et al., 1998). This resistance was attributed to the presence of subcortical dark pigmented granules (with stentorin) (Modenutti et al., 1998; Modenutti et al., 2005) and mycosporin-like aminoacids (Tartarotti et al., 2004). Thus, photoprotection seems to be a predominant strategy in this epilimnetic species.

However, since the metalimnion is included in the euphotic zone autotrophs can avoid the upper levels of the water column developing DCM. Metalimnetic DCM colonization by phototrophic organisms represents a trade-off between higher survival and lower cell-specific primary produc- tion (Modenutti et al., 2004). In particular, 40-80 $\%$ of Chl a concentration at the DCM was observed to be composed by endosymbiotic Chlorella of the ciliate O. naumanni (Queimaliños et al., 1999). This important contribution can be also associated with the raise of $\mathrm{Chl} b$ in Chlorella that allow to profit from the prevailing green and blue wavelengths $(<500 \mathrm{~nm})$ at the DCM (Pérez et al., 2002; Pérez et al., 2007) (Fig. 3).

\section{Living at the edge and stoichiometric balances: high vs low irradiance}

Purely phototrophic organisms tend to increase in $\mathrm{C}$ content and thus in $\mathrm{C}$ : nutrient ratio as light increases (Sterner et al., 1997); however, mixotrophs compensate for increased $\mathrm{C}$ fixation by phagotrophy to obtain $\mathrm{N}$ and $\mathrm{P}$ (Jones, 2000; Modenutti \& Balseiro, 2002). Mixotrophic ciliates combine phagotrophy and phototrophy in the same organism and the combination of these nutritional modes imply a more balanced stoichiometric composition (Flynn \& Mitra, 2009). Also, this combined nutrition seems to confer important ecological advantages as it provides

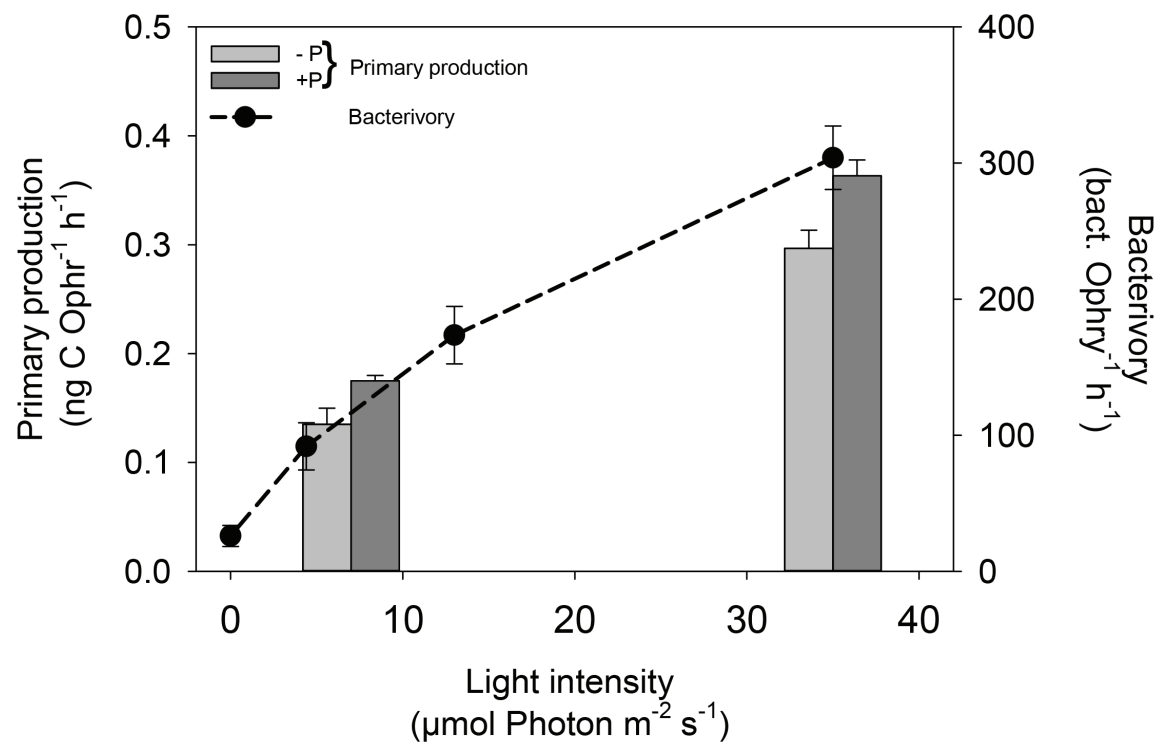

Figure 4. Bacterivory of Ophyrdium naumanni in a light gradient (black dots and dashed lines) and Net Primary Production (NPP) of Ophrydium naumanni cultured with (dark bars) and without (light grey bars) P enriched bacteria. Error bars are 1 s.e. Bacterivoría de Ophyrdium naumanni en un gradiente de luz (puntos negros y línea de guiones) y Producción Primaria Neta (NPP) de Ophrydium naumanni cultivados con (barras oscuras) y sin (barras claras) bacterias enriquecidas en P. Las barras de error indican 1 error estándar. 
greater flexibility in the planktonic environment (Stoecker et al., 2009).

While the sestonic C:P ratio (atomic) of deep North-Patagonian Andean lakes range from 340 to 1200 (Balseiro et al., 2007), the C:P ratio of $S$. araucanus and $O$. naumanni is significantly lower $(170 \pm 27$, mean \pm S.E. $)$ (Modenutti et al., 2018). This balanced C:P ratio represents a noticeably increase in $\mathrm{P}$ content relative to the bulk lake seston. Thus, mixotrophic ciliates show a rather strict stoichiometric homeostasis, meaning that, from a stoichiometric perspective, these species would be a good food source in systems with low food quality (Modenutti et al., 2018).

Mixotrophic ciliate stoichiometric balance may not be the pure result of light-nutrient ratio of the lake because their elemental ratio results of the interactions between photosynthesis and prey consumption. This outcome was clear in the case of $O$. naumanni conforming metalimnetic DCM at $1 \%$ of PAR. Combining field and laboratory experiments $\left({ }^{14} \mathrm{C}\right.$ fixation and bacterivory experiments) we determined that $O$. naumanni balances photosynthesis and prey consumption (Modenutti \& Balseiro, 2002; Modenutti et al., 2004). At low irradiance ( $1 \%$ of surface PAR) $\mathrm{C}$ fixation and bacterivory are both related with light availability as $O$. naumanni ingests more bacteria as $\mathrm{C}$ fixation increases (Fig. 4). Furthermore, if $O$. naumanni is fed with $\mathrm{P}$ enriched bacteria (see dark grey bars in Fig. 4) $\mathrm{C}$ fixation increases when compared with non-enriched prey, at the same light intensity (Fig.4). Summarizing, $O$. naumanni at the DCM (metalimnion) balance $\mathrm{C}$ fixation (autotrophic nutrition) with the $\mathrm{P}$ uptake (phagotrophic nutrition).

However, the ${ }^{14} \mathrm{C}$ fixation experiments carried out with $S$. araucanus gave very different results. As expected for a resistant UVR organism, at 0.3 $\mathrm{m}$ depth the net primary production (NPP) did not decrease in the presence of UV-B wavelength (similar values in quartz tubes vs. quartz tubes wrapped with MylarTM) (Modenutti et al., 2005). Strikingly, we observed no trend in NPP with light, since all conditions (static or moving incubations) with light $>100 \mu \mathrm{mol} \mathrm{m}^{-2} \mathrm{~s}^{-1}$ had NPP $>$ 1 ng C ind ${ }^{-1} \mathrm{~h}^{-1}$ (Fig. 5). However, a significant drop in NPP was observed when light was $<100$ $\mu \mathrm{mol} \mathrm{m} \mathrm{m}^{-2} \mathrm{~s}^{-1}$ (Fig. 5) and this limit is far from the

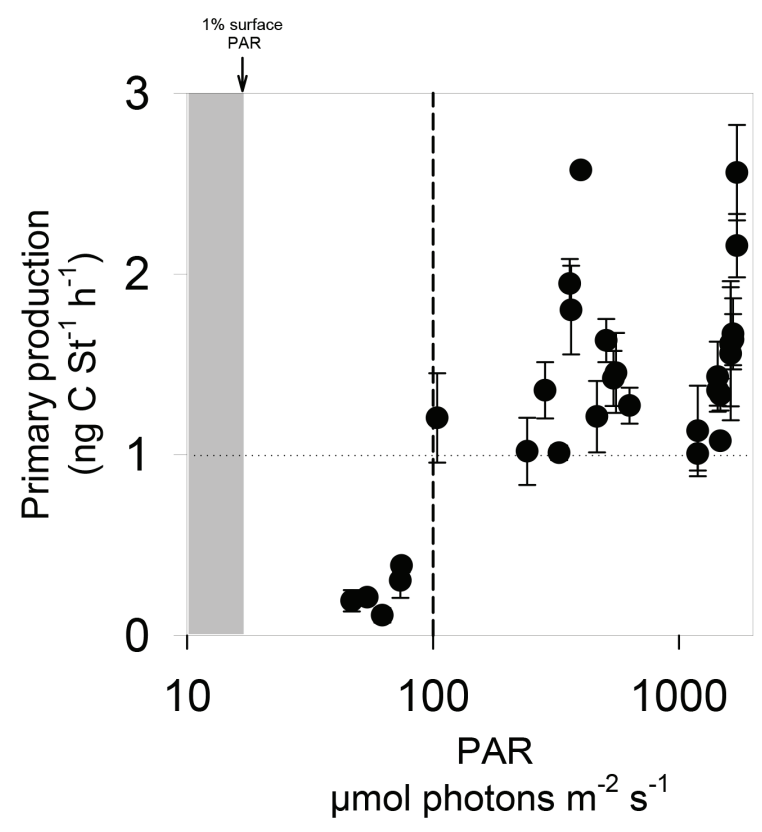

Figure 5. Net Primary Production of Stentor araucanus in fixed and moving incubations, protected or not from UVR. Vertical dashed line indicates $100 \mu \mathrm{mol}$ photon $\mathrm{m}^{-2} \mathrm{~s}^{-1}$, and horizontal dotted lines a NPP of $1 \mathrm{ng} \mathrm{C} \mathrm{St}^{-1} \mathrm{~h}^{-1}$. Note the drop in NPP when light is below $100 \mu \mathrm{mol}$ photon $\mathrm{m}^{-2} \mathrm{~s}^{-1}$. Producción Primaria Neta (NPP) de Stentor araucanus en incubaciones fijas y móviles protegidas o no de la radiación UV. La linea de guiones vertical indica $100 \mu \mathrm{mol}$ fotones $\mathrm{m}^{-2} \mathrm{~s}^{-1}$ y la línea de puntos horizontal muestra NPP de $1 \mathrm{ng} \mathrm{C} \mathrm{St}^{-1} \mathrm{~h}^{-1}$. Nótese la brusca caída en NPP cuando la luz es menor a 100 umol fotones $\mathrm{m}^{-2} \mathrm{~s}^{-1}$.

zone where $O$. naumanni inhabits $(\sim 15 \mu \mathrm{mol} \mathrm{m}-2$ $\left.\mathrm{s}^{-1}\right)$. In addition, the analysis of food vacuoles did not show bacteria inside $S$. araucanus' cell meaning that at least for long summer periods photosynthesis of the endobiosymbiotic algae is the main nutrition mode of this ciliate (Modenutti et al., 2008). The presence of these dark granules act as a light umbrella for the endosymbiotic algae, since stentorin absorbs PAR mainly between 400 and $600 \mathrm{~nm}$ (Moller, 1962; Modenutti et al., 2005). In this sense, the irradiance below 100 $\mu \mathrm{mol}$ photons $\mathrm{m}^{-2} \mathrm{~s}^{-1}$ appeared to be insufficient to allow endosymbiotic algae to produce $(\mathrm{C}$ fixation) under such a dark pigmented umbrella. Consequently, granules have a shading effect and black ciliates such as $S$. araucanus may be able to regulate internal light intensity for endosymbiotic algae and thus, elemental balance in this ciliate 
would be achieved by regulating internal light and not by phagotrophy.

Independently of the stoichiometric strategy involved, the overall seston C:P ratio in a lake with strong influence of such mixotrophs would be lower than that of purely phototrophic organisms (Modenutti et al., 2018). Given that zooplankton predators are constrained by the elemental content of their prey (Laspoumaderes et al., 2015), the stoichiometric balance of mixotrophs may be a key factor affecting the stoichiometry of predator-prey relationships. This was the case of the cyclopoid copepod Mesocyclops araucanus that feeds upon S. araucanus (Kamjunke et al., 2012) at the epilimnion during night (Modenutti et al., 2018). In this relationship it is also important the presence of the pigment stentorin that cause an increase in the oxidative stress of the organisms who prey upon $S$. araucanus. Under these circumstances, $M$. araucanus would be exposed to an increase in visible light stress that drives a diel vertical migration with a deeper distribution (1.5 fold deeper than other microcrustaceans, Daphnia and Boeckella) during day (Modenutti et al., 2018).

\section{The future}

Lakes act as early sentinels to environmental changes (Williamson et al., 2008). In particular, the decline in biodiversity of freshwater biota is higher than for terrestrial or marine organisms (Jenkins \& Boulton, 2003). Thus, it would be crucial to understand the causes and consequences of the loss of biodiversity caused by changes in aquatic ecosystems (Williamson et al., 2008). In this sense, it would be necessary to develop applications of ecological and evolutionary knowledge for addressing environmental problems (Sutherland et al., 2009). At present, this mixotrophic biota is threated by local and global changes that may affect negatively the particular ciliate assemblage of North-Patagonian Andean lakes.

These glacial deep lakes can be considered as sensitive environments to global change. Patagonia is under the influence of the Antarctic ozone "hole" receiving occasionally enhanced levels of ultraviolet B radiation (UVR-B, 280-315 nm) (Villafañe et al., 2001). This condition would cause a number of detrimental effects in aquatic organisms (Zagarese \& Williamson, 1994; Helbling \& Zagarese, 2003). In this sense, pigmented members of the genus Stentor (i.e. $S$. araucanus and S. amethystinus) would be favored because of their high resistance to UVR (Modenutti et al., 1998; Tartarotti et al., 2004). Interannual variations in the thermocline depth due to wind will also cause changes in the mean light intensity of the epilimnion and would affect the coexistence of $S$. araucanus and $O$. naumanni (Modenutti et al., 2008) shifting the ratio of these two species, towards $S$. araucanus if wind decreases or favoring $O$. naumanni if wind becomes stronger.

Glaciers are retreating as a consequence of climate change almost everywhere around the world — including in the Alps, Himalayas, Andes, Rockies, Alaska and Africa (Zemp et al., 2015). In Patagonia, there are clear examples of glacial retraction in the Mount Tronador ice cap (Worni et al., 2012; Ruiz et al., 2015). This situation affects the lakes that receive water from the glaciers, i.e. Lake Mascardi. This lake has two arms (Catedral and Tronador) that can be considered separate lakes since the two arms differ in their hydrology because of three headwater glaciers (Manso, Castaño Overo and Alerce glaciers) that drain only into Mascardi Tronador arm (Modenutti et al., 2013a). Planktonic organisms (i.e. picocyanobacteria) were observed to be sensitive to changes in glacial clay inputs that cause, in turn, a decrease in light (Hylander et al., 2011; Bastidas Navarro et al., 2018). Mixotrophic ciliates are absent in lake sectors that receives glacial clay (i.e. Lake Mascardi Tronador Arm) probably because clay particles interfere with feeding, although populations remain in the areas without such input (i.e. Lake Mascardi Catedral Arm). Another negative effect of suspended particles on this biota was due to volcanic eruptions that produced sudden catastrophic effects. Northern Patagonia is an active volcanic region with historically high eruption frequency (Inbar et al., 1995). The Puyehue-Cordón Caulle Volcanic Complex $\left(40.59^{\circ} \mathrm{S}-72.11^{\circ} \mathrm{W}, 2200 \mathrm{~m}\right.$ a.s.l.) erupted explosively on 4th June 2011 . The volcano produced $1.46 \mathrm{~km}^{3}$ of rhyolitic volcanic material (Silva Parejas et al., 2012), a similar amount 
to that erupted by Mount St. Helens in 1980 . The lakes in the area were covered by this material affecting nutrient inputs and light conditions (Modenutti et al., 2013b). Under these conditions, mixotrophic ciliate disappeared and the microbial food web changed towards a more autotrophic one (diatoms and phytoflagellates), probably due to the interference by the volcanic ash and the improvement in light conditions (i.e. reduced photoinhibition) (Modenutti et al., 2013b).

The main cause of the loss of biodiversity can be attributed to the local influence of human activities on different ecosystems. In fact, human activities have deeply altered lacustrine environments, through the modifications of landscapes, direct exploitation of species or by affecting biogeochemical cycles. Alteration and loss of the habitats is the transformation of the natural areas by different human activities. In the area there is an example of how this situation will affect ciliate biota. The small, closed basin of Lake Morenito (418S, 718W; $764 \mathrm{~m}$ a.s.1.; $0.82 \mathrm{~km}^{2}$; $12 \mathrm{~m}$ maximum depth) is located $20 \mathrm{~km}$ west from the city of Bariloche and until 1960 this lake was a bay of Lake Moreno West (Modenutti et al., 2000). At that time a road was constructed, separating this bay and creating the new Lake Morenito. In the new lake a littoral zone where Schoenoplectus californicus increased its relative importance and the water exchange with the main basin was deeply reduced. As a consequence dissolved organic matter increased in the new lake in comparison with the original Lake Moreno $(0.5 \mathrm{mg} / \mathrm{L}$ in Lake Moreno vs $3 \mathrm{mg} / \mathrm{L}$ in Lake Morenito) (Modenutti et al., 2000). This situation caused a change in light climate of the new Lake Morenito shifting the blue-green under water climate of Lake Moreno (Fig. 2) to a red predominance (Pérez et al., 2002). These changes would be the key factors for the absence of the two mixotrophic ciliate species (rich in $\mathrm{Chl} \mathrm{b)} \mathrm{(Modenutti} \mathrm{et} \mathrm{al.,}$ 2000). Interestingly, the studies of short sediment cores from Lake Morenito showed a change in the chironomid assemblage in response to an increase in trophic enrichment after the road was constructed (Massaferro et al., 2005). Thus, biota diversity can be severely affected by this kind of change in landscape and basin.

Summarizing, these final considerations imply that endemic elements, such as mixotrophic ciliates, can disappear being replaced by other species of more autotrophic metabolism. From an ecosystem perspective, lake functioning will result altered because of the replacement of the links in the microbial food web. Thus, the loss of this particular biota would drive changes in nutrient recycling, in top down and bottom up effects and in the major ecosystem services.

\section{ACKNOWLEDGEMENTS}

We thank all people involved in past and present studies of mixotrophic ciliates in Andean lakes, and the Iberian Association of Limnology (AIL) for their invitation to present our research in a plenary talk at the Limnology 2018 congress in Coimbra and the present paper.

\section{REFERENCES}

ALONSO, C., V. ROCCO, J. P. BARRIGA, M. A. BATTINI \& H. ZAGARESE. 2004. Surface avoidance by freshwater zooplankton: Field evidence on the role of ultraviolet radiation. Limnology and Oceanography, 49: 225-232.

ANDERSEN, T., J. J. ELSER \& D. O. HESSEN. 2004. Stoichiometry and population dynamics. Ecology Letters, 7: 884-900. DOI: 10.1111/j.1461-0248.2004.00646.x

BAIGÚN, C. \& M. C. MARINONE. 1995. Cold-temperate lakes of South America: do they fit Northern hemisphere models? Archiv fur Hydrobiologie, 135: 23-51.

BALSEIRO, E. G., C. P. QUEIMALIÑOS \& B. E. MODENUTTI. 2004. Grazing impact on autotrophic picoplankton in two south andean lakes (Patagonia, Argentina) with different light:nutrient ratios. Revista Chilena de Historia Natural, 77: 73-85.

BALSEIRO, E. G., B. E. MODENUTTI, C. QUEIMALIÑOS \& M. REISSIG. 2007. Daphnia distribution in Andean Patagonian lakes: effect of low food quality and fish predation. Aquatic Ecology, 41: 599-609.

BASTIDAS NAVARRO, M., N. MARTYNIUK, E. BALSEIRO \& B. MODENUTTI. 2018. Effect of glacial lake outburst floods on the 
light climate in an Andean Patagonian lake: implications for planktonic phototrophs. Hydrobiologia, 816: 39-48.

CALLIERI, C., B. E. MODENUTTI, C. QUEIMALIÑOS, R. BERTONI \& E. G. BALSEIRO. 2007. Production and biomass of picophytoplankton and larger autotrophs in Andean ultraoligotrophic lakes: Differences in light harvesting efficiency in deep layers. Aquatic Ecology, 41: 511-523.

CORNO, G., B. E. MODENUTTI, C. CALLIERI, E. G. BALSEIRO, R. BERTONI \& E. CARAVATI. 2009. Bacterial diversity and morphology in deep ultraoligotrophic Andean lakes: The role of UVR on vertical distribution. Limnology and Oceanography, 54: 1098-1112.

ELSER, J. J. \& R. P. HASSETT. 1994. Stoichiometric analysis of the zooplankton-phytoplankton interaction in marine and freshwater ecosystem. Nature, 370: 211-213.

FALKOWSKI, P. G. \& J. A. RAVEN 2007 Aquatic photosynthesis, 2nd edition ed. Blackwell Science, Malden, MA, USA.

FLYNN, K. J. \& A. MITRA. 2009. Building the "perfect beast": modelling mixotrophic plankton. Journal of Plankton Research, 31: 965-992. DOI: 10.1093/plankt/fbp044

FOISSNER, W. \& S. WOELFL. 1994. Revision of the genus Stentor Oken (Protozoa, Ciliophora) and description of S. araucanus nov. spec. from South American lakes. Journal of Plankton Research, 16: 255-289.

HELBLING, W. \& H. E. ZAGARESE. 2003. UV effect on aquatic organisms and ecosystems. Royal Society of Chemistry,

HESSEN, D. O., P. J. FÆRØVIG \& T. ANDERSEN. 2002. Light, nutrients, and P:C ratios in algae: grazer performance related to food quality and quantity. Ecology, 83: 1886-1898.

HYLANDER, S., T. JEPHSON, K. LEBRET, J. VON EINEM, T. FAGERBERG, E. G. BALSEIRO, B. E. MODENUTTI, M. S. SOUZA, C. LASPOUMADERES, M. JÖNSSON, P. LJUNGBERG, A. NICOLLE, P. A. NILSSON, L. RANÅKER \& L.-A. HANSSON. 2011. Climate-induced input of turbid glacial meltwater affects vertical distribution and community composition of phyto- and zooplankton. Journal of Plankton Research, 33: 1239-1248. DOI: 10.1093/plankt/fbr025

INBAR, M., H. OSTERA, C. PARICA, M. REMESAL \& F. SALANI. 1995. Environmental assessment of 1991 Hudson volcano eruption ashfall effects on southern Patagonia region, Argentina. Environmental Geology, 25: 119-125.

JENKINS, K. M. \& A. J. BOULTON. 2003. Connectivity in a dryland river: short-term aquatic microinvertebrate recruitment following floodplain inundation. Ecology, 84: 2708-2723.

JONES, H. L. J. 1997. A classification of mixotrophic protists based on their behaviour. Freshwater Biology, 37: 35-43.

JONES, R. I. 2000. Mixotrophy in planktonic protists: an overview. Freshwater Biology, 45: 219-226.

KAMJUNKE, N., M. KRAMPS, S. CHAVEZ \& S. WOELFL. 2012. Consumption of large, Chlorella-bearing ciliates (Stentor) by Mesocyclops araucanus in North Patagonian lakes. Journal of Plankton Research, 34: 922-927. DOI: 10.1093/plankt/fbs051

LASPOUMADERES, C., B. MODENUTTI, J. ELSER \& E. BALSEIRO. 2015. Does the stoichiometric carbon:phosphorus knife edge apply for predaceous copepods? Oecologia, 178: 557-569. DOI: $10.1007 / \mathrm{s} 00442-014-$ 3155-8

LAYBOURN-PARRY, J., S. J. PERRISS, G. G. R. SEATON \& J. ROHOZINSKI. 1997. A mixotrophic ciliate as a major contributor to plankton photosynthesis in Australian lakes. Limnology and Oceanography, 42: 1463-1467. LESSER, M. P. 1996. Acclimation of phytoplankton to UV-B radiation: oxidative stress and photoinhibition of photosynthesis are not prevented by UV-absorbing compounds in the dinoflagellate Prorocentrum micans. Marine Ecology Progress Series, 132: 287-297.

MACEK, M., K. ŠIMEK \& T. BITTL. 2001. Conspicuous Peak of Oligotrichous Ciliates Following Winter Stratification in a Bog Lake. Journal of Plankton Research, 23: 353-363(311).

MASSAFERRO, J., S. R. GUEVARA, A. RIZZO \& M. ARRIBÉRE. 2005. Short-term 
environmental changes in Lake Morenito ( $41^{\circ}$ $\mathrm{S}, 71^{\circ} \mathrm{W}$, Patagonia, Argentina) from the analysis of sub-fossil chironomids. Aquatic Conservation: Marine and Freshwater Ecosystems, 15: 23-30. DOI: 10.1002/aqc.640 MITRA, A., K. J. FLYNN, U. TILLMANN, J. A. RAVEN, D. CARON, D. K. STOECKER, F. NOT, P. J. HANSEN, G. HALLEGRAEFF, R. SANDERS, S. WILKEN, G. MCMANUS, M. JOHNSON, P. PITTA, S. VAGE, T. BERGE, A. CALBET, F. THINGSTAD, H. J. JEONG, J. BURKHOLDER, P. M. GLIBERT, E. GRANELI \& V. LUNDGREN. 2016. Defining Planktonic Protist Functional Groups on Mechanisms for Energy and Nutrient Acquisition: Incorporation of Diverse Mixotrophic Strategies. Protist, 167: 106-120. DOI: $10.1016 /$ j.protis.2016.01.003

MODENUTTI, B. E. 1997. Distribución de los ciliados planctónicos Ophrydium naumanni y Stentor araucanus en lagos oligotróficos andinos. Revista de la Sociedad Mexicana de Historia Natural, 47: 79-83.

MODENUTTI, B. E., E. G. BALSEIRO \& R. MOELLER. 1998. Vertical distribution and resistance to ultraviolet radiation of a planktonic ciliate Stentor araucanus. Verhandlungen Internationale Vereinigung Limnologie, 26: 1636-1640.

MODENUTTI, B. E., E. G. BALSEIRO \& C. P. QUEIMALIÑOS. 2000. Ciliate community structure in two South Andean lakes: the effect of lake water on Ophrydium naumanni distribution. Aquatic Microbial Ecology, 21: 299-307.

MODENUTTI, B. E. \& E. G. BALSEIRO. 2002. Mixotrophic ciliates in an Andean lake: dependence on light and prey of an Ophrydium naumanni population. Freshwater Biology, 47: 121-128.

MODENUTTI, B. E., E. G. BALSEIRO, C. CALLIERI, C. QUEIMALIÑOS \& R. BERTONI. 2004. Increase in photosynthetic efficiency as a strategy of planktonic organisms exploiting deep lake layers. Freshwater Biology, 49: 160-169.

MODENUTTI, B. E., E. G. BALSEIRO, C. CALLIERI, R. BERTONI \& C. P. QUEIMALIÑOS. 2005. Effect of UV-B and different
PAR intensities on the primary production of the mixotrophic planktonic ciliate Stentor araucanus. Limnology and Oceanography, 50: 864-871.

MODENUTTI, B. E., E. G. BALSEIRO, C. CALLIERI \& R. BERTONI. 2008. Light versus food supply as factors modulating niche partitioning in two pelagic mixotrophic ciliates. Limnology and Oceanography, 53: 446-455.

MODENUTTI, B. E., E. G. BALSEIRO, M. BASTIDAS NAVARRO, C. LASPOUMADERES, M. S. SOUZA \& F. CUASSOLO. 2013a. Environmental changes affecting light climate in oligotrophic mountain lakes: The deep chlorophyll maxima as a sensitive variable. Aquatic Sciences, 75: 361-371. DOI: 10.1007/s00027-012-0282-3

MODENUTTI, B. E., E. G. BALSEIRO, J. J. ELSER, M. BASTIDAS NAVARRO, F. CUASSOLO, C. LASPOUMADERES, M. S. SOUZA \& V. DiAZ VILLANUEVA. 2013b. Effect of volcanic eruption on nutrients, light, and phytoplankton in oligotrophic lakes. Limnology and Oceanography, 58: 1165-1175. DOI: 10.4319/10.2013.58.4.0000

MODENUTTI, B. E. 2014. Mixotrophy in Argentina freshwaters. Advances in limnology, 65: 359-374.

MODENUTTI, B. E., L. WOLINSKI, M. S. SOUZA \& E. G. BALSEIRO. 2018. When eating a prey is risky: Implications for predator diel vertical migration. Limnology and Oceanography, 63: 939-950. DOI: 10.1002/lno.10681

MOLLER, K. M. 1962. On the nature of stentorine. Compte rendue travaux Carlsberg, 32: 471-498.

MORRIS, D. P., H. ZAGARESE, C. E. WILLIAMSON, E. G. BALSEIRO, B. R. HARGREAVES, B. E. MODENUTTI, R. MOELLER \& C. QUEIMALIÑOS. 1995. The attenuation of solar UV radiation in lakes and the role of dissolved organic carbon. Limnology and Oceanography, 40: 1381-1391.

PÉREZ, G. L., C. P. QUEIMALIÑOS \& B. E. MODENUTTI. 2002. Light climate and plankton in the deep chlorophyll maxima in North Patagonian Andean lakes. Journal of Plankton Research, 24: 591-599. 
PÉREZ, G. L., C. QUEIMALIÑOS, E. G. BALSEIRO \& B. E. MODENUTTI. 2007. Phytoplankton absorption spectra along the water column in deep North Patagonian Andean lakes (Argentina): Limnology of Temperate South America. Limnologica, 37: 3-16.

PERRISS, S. J., J. LAYBOURN-PARRY \& R. I. JONES. 1994. Chlorophyll contents and photosynthetic rates of the freshwater mixotrophic ciliate Strombidium viride (Ciliophora: Oligotrichida). Archiv fur Hydrobiologie, 130: 473-483.

PUTT, M. 1990. Abundance, chlorophyll content and photosynthetic rates of ciliates in the Nordic Seas during summer. Deep Sea Research Part A, Oceanographic Research Papers, 37: 1713-1731.

QUEIMALIÑOS, C. P., B. E. MODENUTTI \& E. G. BALSEIRO. 1999. Symbiotic association of the ciliate Ophrydium naumanni with Chlorella causing a deep chlorophyll a maximum in an oligotrophic South Andes lake. Journal of Plankton Research, 21: 167-178.

REISSER, W., R. MEIER, H. D. GORTZ \& K. W. JEON. 1985. Establishment, Maintenance, and integration mechanisms of endosymbionts in Protozoa. Journal of Protozoology, 32: 383-390.

RUIZ, L., E. BERTHIER, H. M. MASIOKAS, P. PITTE \& R. VILLALBA. 2015. First surface velocity maps for glaciers of Monte Tronador, North Patagonian Andes, derived from sequential Pléiades satellite images. Journal of Glaciology, 61: 908-922. DOI: 10.3189/ 2015JoG14J134

SILVA PAREJAS, C., L. LARA, D. BERTIN, A. AMIGO \& G. OROZCO. 2012. The 2011-2012 eruption of Cordón Caulle volcano (Southern Andes): Evolution, crisis management and current hazards, p. 9382. EGU General Assembly Conference Abstracts.

STERNER, R. W., J. J. ELSER, E. J. FEE, S. J. GUILDFORD \& T. H. CHRZANOWSKI. 1997. The light:nutrient ratio in lakes: The balance of energy and materials affects ecosystem structure and process. The American Naturalist, 150: 663-684.

STERNER, R. W. \& J. J. ELSER. 2002. Ecological stoichiometry. The biology of elements from molecules to the biosphere. Princeton University Press, Princeton, NJ USA.

STOECKER, D. K. \& M. W. SILVER. 1987. Chloroplast retention by marine planktonic ciliates. Annals of the New York Academy of Sciences, 503: 562-565.

STOECKER, D. K. 1998. Conceptual models of mixotrophy in planktonic protists and some ecological and evolutionary implications. European Journal of Protistology, 34: 281-290.

STOECKER, D. K., M. D. JOHNSON, C. DE VARGAS \& F. NOT. 2009. Acquired phototrophy in aquatic protists. Aquatic Microbial Ecology, 57: 279-310.

SUMMERER, M., B. SONNTAG \& R. SOMMARUGA. 2008. Ciliate-symbiont specificity of freshwater endosymbiotic Chlorella (Trebouxiophyceae, Chlorophyta). Journal of Phycology, 44: 77-84.

SUTHERLAND, W. J., W. M. ADAMS, R. B. ARONSON, R. AVELING, T. M. BLACKBURN, S. BROAD, G. CEBALLOS, I. M. COTE, R. M. COWLING, G. A. DA FONSECA, E. DINERSTEIN, P. J. FERRARO, E. FLEISHMAN, C. GASCON, M. HUNTER, JR., J. HUTTON, P. KAREIVA, A. KURIA, D. W. MACDONALD, K. MACKINNON, F. J. MADGWICK, M. B. MASCIA, J. MCNEELY, E. J. MILNER-GULLAND, S. MOON, C. G. MORLEY, S. NELSON, D. OSBORN, M. PAI, E. C. PARSONS, L. S. PECK, H. POSSINGHAM, S. V. PRIOR, A. S. PULLIN, M. R. RANDS, J. RANGANATHAN, K. H. REDFORD, J. P. RODRIGUEZ, F. SEYMOUR, J. SOBEL, N. S. SODHI, A. STOTT, K. VANCE-BORLAND \& A. R. WATKINSON. 2009. One hundred questions of importance to the conservation of global biological diversity. Conservation Biology, 23: 557-567. DOI: 10.1111/j.15231739.2009.01212.x

TARTAROTTI, B., G. BAFFICO, P. TEMPORETTI \& H. E. ZAGARESE. 2004. Mycosporine-like amino acids in planktonic organisms living under different UV exposure conditions in Patagonian lakes. Journal of Plankton Research, 26: 753-762.

THOMASSON, K. 1963. Araucanian lakes. Acta 
Phytogeographica Sueca, 47: 1-139.

TITTEL, J., V. BISSINGER, B. ZIPPEL, U. GAEDKE, E. BELL, A. LORKE \& N. KAMJUNKE. 2003. Mixotrophs combine resource use to outcompete specialists: Implications for aquatic food webs. Proceeding of the National Academy of Sciences, 100: 12776-12781.

VILLAFAÑE, V., E. W. HELBLING \& H. E. ZAGARESE. 2001. Solar ultraviolet radiation and its impact on aquatic systems of Patagonia, South America. Ambio, 30: 112-117.

VILLAFAÑE, V. E., A. G. J. BUMA, P. BOELEN \& E. W. HELBLING. 2004. Solar UVR-induced DNA damage and inhibition of photosynthesis in phytoplankton from Andean lakes of Argentina. Archiv fur Hydrobiologie, 161: 245-266.

WILLIAMSON, C. E., W. DODDS, T. K. KRATZ \& M. A. PALMER. 2008. Lakes and streams as sentinels of environmental change in terrestrial and atmospheric processes. Frontiers in Ecology and the Environment, 6: 247-254.

WOELFL, S. \& W. GELLER. 2002. Chlorella-bearing ciliates dominate in an oligotrophic North Patagonian lake (Lake Pirehueico, Chile): abundance, biomass and symbiotic photosynthesis. Freshwater Biology, 47: 231-242.

WORNI, R., M. STOFFEL, C. HUGGEL, C. VOLZ, A. CASTELLER \& B. LUCKMAN.
2012. Analysis and dynamic modeling of a moraine failure and glacier lake outburst flood at Ventisquero Negro, Patagonian Andes (Argentina). Journal of Hydrology, 444-445: 134-145. DOI: 10.1016/j.jhydrol.2012.04.013 ZAGARESE, H. E. \& C. WILLIAMSON. 1994. Modeling the impact of UV-B radiation on ecological interactions in freshwater and marine ecosystems. In: Stratospheric ozone depletion $/ U V-B$ radiation in the biosphere. $\mathrm{R}$. H. Biggs \& M. E. B. Joyner (ed.):315-328. Springer Verlag, Berlin, Germany.

ZEMP, M., H. FREY, I. GÄRTNER-ROER, S. U. NUSSBAUMER, M. HOELZLE, F. PAUL, W. HAEBERLI, F. DENZINGER, A. P. AHLSTRØM, B. ANDERSON, S. BAJRACHARYA, C. BARONI, L. N. BRAUN, B. E. CÀCERES, G. CASASSA, G. COBOS, L. R. DÀVILA, H. DELGADO GRANADOS, M. N. DEMUTH, L. ESPIZUA, A. FISCHER, K. FUJITA, B. GADEK, A. GHAZANFAR, J. O. HAGEN, P. HOLMLUND, N. KARIMI, Z. LI, M. PELTO, P. PITTE, V. V. POPOVNIN, C. A. PORTOCARRERO, R. PRINZ, C. V. SANGEWAR, I. SEVERSKIY, O. SIGURDSSON, A. SORUCO, R. USUBALIEV \& C. VINCENT. 2015. Historically unprecedented global glacier decline in the early $21^{\text {st }}$ century. Journal of Glaciology, 61: 745-762. DOI: 10.3189/2015JoG15J017

Con el patrocinio de:

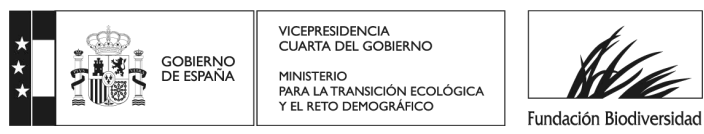

